\title{
Fish utilisation of managed realignments
}

\author{
S. COLCLOUGH, L. FONSECA, T. ASTLEY, K. THOMAS \& W. WATTS \\ Environment Agency Thames Region, South East Area, Abbey Wood, London, UK
}

\begin{abstract}
One area of ecological benefit not yet fully evaluated in European waters is the utilisation of restored saltmarsh habitats by fish species. This study examines the utilisation of managed realignments and relic saltmarsh by fish species. Factors affecting habitat heterogeneity and fish populations are discussed, and recommendations are made with respect to scheme design and management that will maximise the biological and socio-economic values. Fish populations in the high intertidal areas were assessed using a suite of techniques, including observations on feeding behaviour. Each microhabitat was discussed as a function of the extent of fish colonisation. A positive relationship between the degree of fish utilisation and habitat heterogeneity was ascertained using species richness, abundance and behavioural observations. This study will aid habitat valuation for economic justification of managed realignments, over and above existing drivers, such as compensatory habitat for encroachment, flood defence and the European Union Habitats Directive. The work now forms part of a wider European Interreg IIIb project, COMCOAST.
\end{abstract}

KEYWORDS: fish, habitat, intertidal, managed realignment, saltmarsh.

\section{Introduction}

Saltmarshes in the UK are a valuable, but diminishing, resource. They are known to possess critical biological, chemical and ecological functions, and contribute to flood defence by dissipating wave energy (Dixon, Leggett \& Weight 1998). These key functions are now being compromised. These habitats are threatened by cumulative anthropogenic demands on intertidal habitats for agriculture, port development, harbours, industry, recreation and housing. Attrill, Bilton, Rowden, Rundle \& Thomas (1999) reported that land claim has affected $85 \%$ of British estuaries. In some cases, over $80 \%$ of the intertidal area has been lost.

South-east England is particularly vulnerable to elevated sea level rise (current rate of $1-1.5 \mathrm{~mm} \mathrm{yr}^{-1}$ ) because of post-glacial land subsidence caused by isostatic rebound. This is contributing to the phenomenon of coastal squeeze, where the seaward habitat is diminished through sea level rise, whilst sea defence structures, such as sea walls, are limiting compensatory inland encroachment (Crooks \& Turner 1999). Two per cent of English saltmarshes are lost to the sea every year as a consequence of sea level rise (Dixon et al. 1998).
Saltmarsh habitats support distinctive plant communities and associated fauna; they are important feeding, breeding and roosting grounds for birds (Rupp \& Nicholls 2002). Saltmarshes are a UK Biodiversity Action Plan habitat and, in England, form part of the Government (Department for Environment and Rural Affairs) High Level Target nine habitat series. Under these initiatives the intention is that there should be no further net loss of habitat and opportunities for environmental enhancement should be sought.

A substantial body of North American work has reported on the importance of the intertidal zone and salt marshes for feeding, refuge and nursery areas for fish life (Rountree \& Able 1992; Peterson \& Turner 1994; West \& Zedler 2000). Several authors reported on the value of these habitats as integral elements in local recreational and commercial fisheries (Shenker \& Dean 1979; Boesch \& Turner 1984; Bell 1997). Between 1950 and 1970, the US Fish and Wildlife Service documented a loss of 68000 ha of coastal vegetated wetlands in the 48 states, due mainly to urban development, with consequential serious loss of fish production (Bell 1997). Fewer studies have taken place 
in North West Europe, probably in part a reflection of the sampling difficulties inherent in large tidal ranges (Elliott \& Taylor 1989; Laffaille, Feunteun \& Lefeuvre 2000; Mathieson, Cattrijsse, Costa, Drake, Elliott, Gardner \& Marchand 2000; Laffaille, Lefeuvre, Schricke \& Feunteun 2001; Lyndon, Bryson, Holding \& Moore 2002). Several workers have commented on the historic loss of intertidal habitat and saltmarshes, and the consequent reduction in fish production. McLusky, Bryant \& Elliott (1992) estimated that the fish populations associated with the Forth estuary would be some $66 \%$ greater if the historic land claim over the past 200 hundred years had never occurred.

Encroachment onto the intertidal foreshore is an extreme pressure on estuaries. In the Thames estuary in the UK, $<1 \%$ of the original bank form remains (Colclough, Gray, Bark \& Knights 2002). Encroachment can reduce flood storage capacity, increase scour and flow, and remove important intertidal foreshore habitat. The aggregate impacts of encroachment can impede the migration of fish fry, which use selective tidal stream transport (Colclough et al. 2002).

The special significance of the high intertidal zone to fish has been noted by several workers. Elliott \& Taylor (1989) reported that intertidal habitats in the Forth were at least twice as productive as their subtidal counterparts, with estimated production of 0.077 and $0.032 \mathrm{t} \mathrm{ha}^{-1}$, respectively. Hettler (1989) estimated an annual production for fish in the littoral zone of an estuary in North Carolina (USA) at $0.0475 \mathrm{t} \mathrm{ha}^{-1}$. Laffaille et al. (2001) noted that 0-group bass Dicentrarchus labrax (L.) could only enter the macro-tidal saltmarsh and intertidal creeks in Mont Saint-Michel Bay (France) for 1-2 h on spring tides ( $43 \%$ of the tides), and that foraging in the vegetated areas was only possible for about $5 \%$ of the time. However, the authors demonstrated that primary and secondary production of intertidal salt marshes plays a fundamental role in the feeding of 0 -group bass and they noted that the nursery function usually ascribed to subtidal and intertidal flats should be extended to the supratidal, vegetated marshes and to salt marsh creeks. Fish populations also move onto the high intertidal and saltmarsh areas on flood tides and then returned to deeper water on the ebb (Lyndon et al. 2002).

Over the past 20 years, greater consideration has been given to the employment of soft measures in the protection of UK coasts (Klein, Smit, Goosen \& Hulsbergen 1998; Leafe, Pethick \& Townend 1998). Managed realignment is the process of setting back the line of actively maintained coastal defences, either through a breach or total removal of the dike or sea wall, to dissipate wave energy and encourage intertidal habitat establishment between the old and new defences (Rupp \& Nicholls 2002). Realignment can incorporate new mudflats and saltmarshes.

This paper reports on the utilisation of saltmarsh and managed realignment treatments by fish populations at five sites in southern England. It will be used to support future habitat evaluation of managed realignments, provide guidance on appropriate sampling methodologies and recommendations on site design to maximise fish utilisation. An attempt is made to obtain information on fish behaviour within the high intertidal areas of managed realignments, in addition to that relating to lower intertidal creeks.

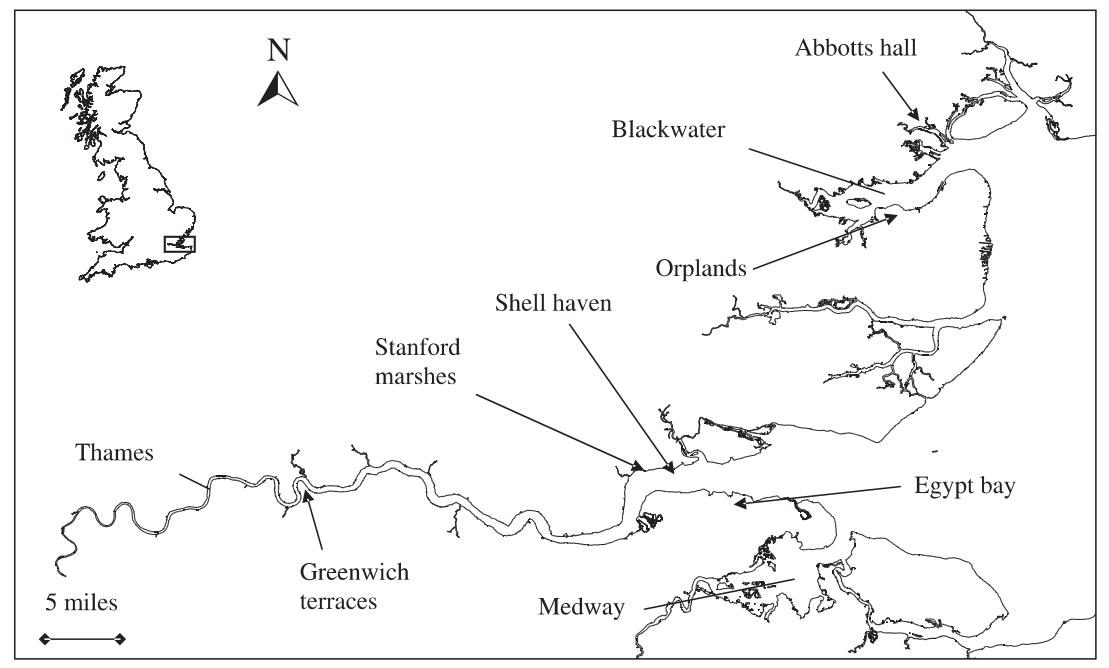

Figure 1. The Greater Thames Estuary and sampling sites. 


\section{Study sites}

Five sites (Fig. 1) were selected for the study of realignment, of which three, were in the Thames Estuary and two in the Blackwater Estuary. The Thames estuary runs for $112 \mathrm{~km}$ from the tidal limit at Teddington to Southend-on-Sea. Substantial loss of intertidal areas has occurred throughout much of its length because of encroachment for development. However, recovery of the estuary from gross pollution since 1960 has brought recovery of important bird and fish communities (see review by Colclough et al. 2002). The Blackwater Estuary stretches some $23 \mathrm{~km}$ from Maldon to Mersea Island, and is much less developed than the main Thames Estuary. Intertidal areas consist of mudflats bordered by extensive saltmarshes.

Descriptions of the realignment actions are as follows.

At Abbotts Hall (Blackwater Estuary) (Fig. 2) the sea wall was breached locally at five points in October 2002 to create 80 ha of diverse wetland. No retired sea defence wall was created and the high intertidal area now extends directly to the edge of the managed fields.

The sea wall at Orplands (Blackwater Estuary) (Fig. 3) was breached in two places in April 1995 to create a 38-ha site separated into two sections by a counterwall. The width of the breaches were designed to allow future widening and the main borrow pit was designed as a sediment trap. Human engineering was reduced to a minimum (Dixon et al. 1998).

New tidal defences immediately in front of the Millenium Dome Exhibition site at Greenwich (Fig. 4) were completed in 1998 during site construction. The existing failing defences were cut down and the land behind reshaped to form stepped terraces lying between mean high water and mean spring tide to encourage growth of intertidal macrophytes. The macrophytes and terraces provide a mosaic of intertidal habitats for invertebrates, birds and fish. Two sections of realignment were created, one of $130 \mathrm{~m}$ with $10 \mathrm{~m}$ deep terraces and another of $1300 \mathrm{~m}$ with 7-m terraces.

In mitigation for the loss of fish productivity associated with the redevelopment of the former Shell Haven Refinery site (Thames Estuary) as a major container port, now named London Gateway, 90 ha of new intertidal habitat is planned. Compensation sites were agreed adjacent to Egypt Bay on the Kent shore and to Stanford Marshes (Fig. 5) on the Essex shore; both sites support modest areas of saltmarsh at present.

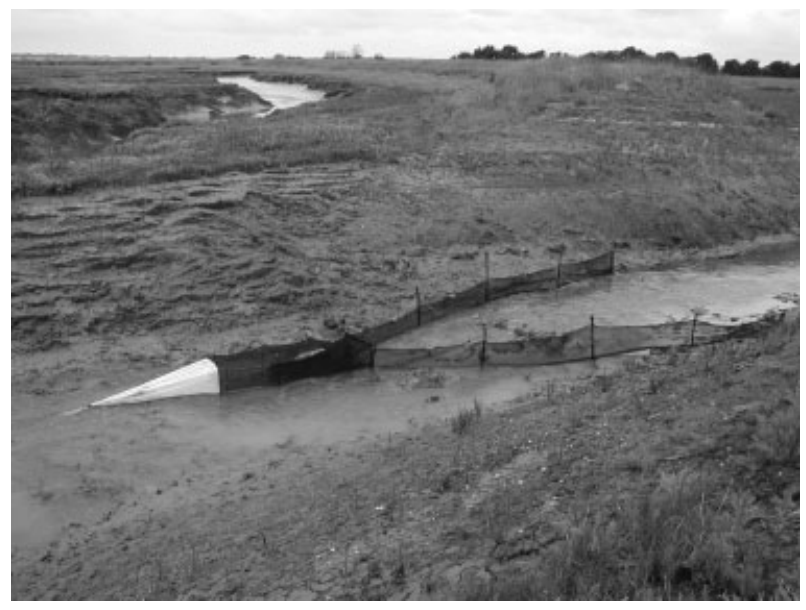

Figure 2. Abbotts Hall; Salcott Channel, Blackwater Estuary.

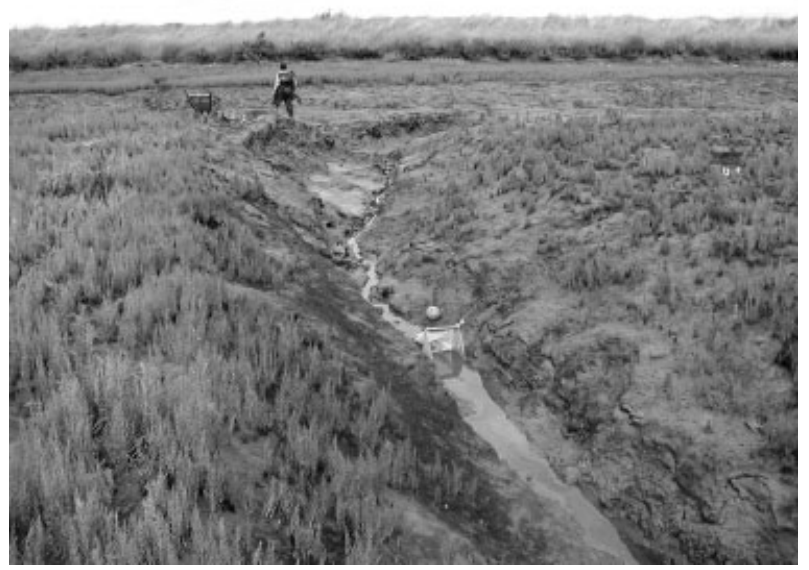

Figure 3. Orplands; St Lawrence Bay, Blackwater Estuary.

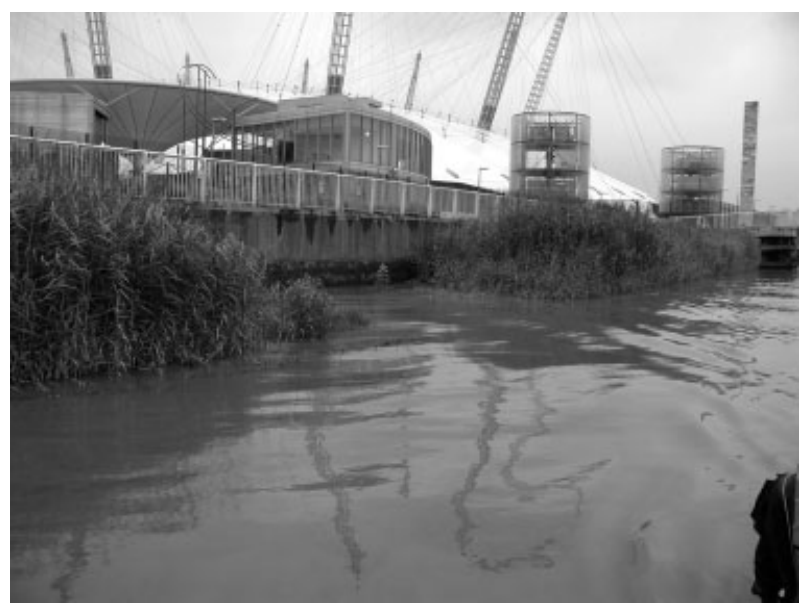

Figure 4. Greenwich Millenium Terraces; Greenwich, Thames Estuary. 


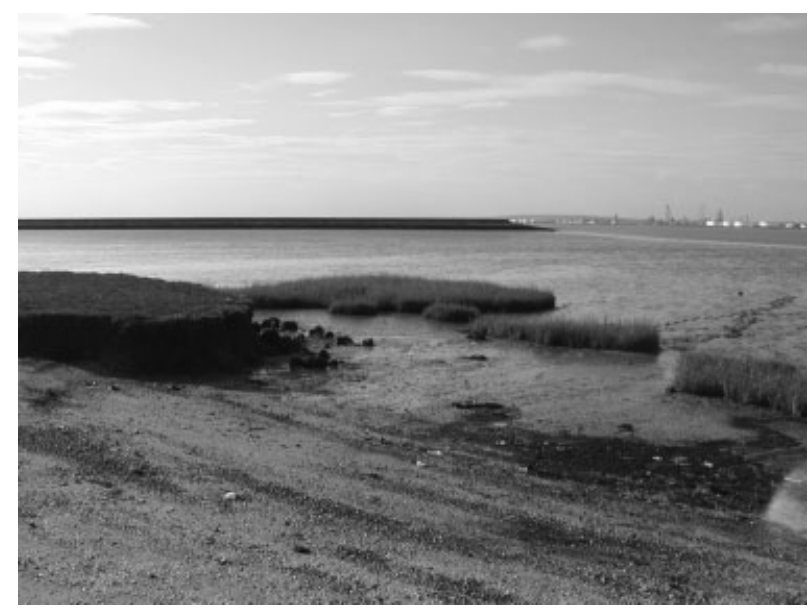

Figure 5. London Gateway Port Development Compensation Lands; Stanford Marshes (near Stanford le Hope) Thames Estuary.

\section{Methods}

Few studies have been conducted on intertidal fish communities in Western Europe. Most estuarine fish sampling programmes have tended to rely on a single capture method (Hemingway \& Elliott 2002). A multiple-method, fish sampling strategy employed by the Environment Agency of England and Wales on the Thames estuary since 1992 (Colclough, Coates, Dutton, Cousins \& Astley 2003) has been recognised as a unique example of European Best Practice (Hemingway \& Elliott 2002). Intertidal areas are so dynamic that the application of a range of qualitative techniques in a standard seasonal format at fixed sites over the long term represents the best chance of developing a robust mosaic picture of the status of local fish communities. The sampling rationale involved now forms the basis for a new UK strategy to meet the requirements of the European Water Framework Directive in transitional (estuarine) waters.

The rationale behind the transitional waters sampling strategy transfers well to shallow intertidal saltmarsh environments. Tow nets, used for larval fish studies, are inappropriate in shallow estuarine areas (Southward 1970). In this study, the static methods employed by both Laffaille et al. (2001) and Lyndon et al. (2002) were combined with sampling strategies developed from the Environment Agency methodology.

Rectangular static nets $(2.5 \mathrm{~m} \times 500 \mathrm{~mm} \times 400 \mathrm{~mm})$, with 4-mm knotless mesh, 1-mm knotless cod end, 4$\mathrm{mm}$ knotless inscale with twin $5-\mathrm{m}$ wings $(30 \mathrm{~cm}$ high), were staked out in and around breaches in the sea wall associated with realignment and in major creek systems inside and outside of the breaches (see, for example, Fig. 2). The nets were set at low water and retrieved at the next low water. The nets sampled fish draining off the upper marsh areas through the creek systems. Bozeman \& Dean (1980) reported problems with sampling velocities, and similar problems were encountered in this case. Depending upon precise location, the nets were considered to be sampling most of the fish populations leaving the marsh on the ebb, but the results cannot be considered to be fully quantitative.

During the upper part of the tidal cycle, seven other methods were employed to study fish utilisation in the upper creeks and saltmarsh:

- a $35 \mathrm{~m} \times 2 \mathrm{~m}$ knotless mesh seine net with 5-mm centre and $10-\mathrm{mm}$ wings was deployed repeatedly at appropriate locations at or near high water slack tide; - a $10 \mathrm{~m} \times 1 \mathrm{~m}$ knotless seine net (5-mm mesh) was deployed as above;

- a standard Freshwater Biological Association kick net with $1-\mathrm{mm}$ mesh was deployed for $1 \mathrm{~min}$ in the high intertidal zone around saltmarsh vegetation stands to sample early fry and post-larvae;

- passive samplers derived from Surber samplers with 1-mm mesh, were deployed for short periods with anchors in areas where temporary steady focussed unidirectional flows occurred during the ebb, to sample early fry and post-larvae;

- baited minnow traps with weights and float were deployed in small intertidal creeks;

- a $3 \mathrm{~m} \times 1 \mathrm{~m}$ push net with 4-mm mesh was deployed in areas of harder ground around vegetation stands at or near high slack water;

- visual observations of fish movement and behaviour were made in the creeks and around the stands of vegetation.

\section{Results}

Restored intertidal saltmarsh was well utilised by juvenile fishes, which show preferences for particular microhabitats (Table 1). Abbotts Hall managed realignment was particularly beneficial to fish fry, which were observed in close association with vegetation stands. This site is notable in that colonisation by saltmarsh plants has been faster than on earlier realignments sites, such as Orplands. This may reflect both the timing of breaching and the use of regulated tidal exchange (K. Thomas, personal communication). Habitat heterogeneity was found to be important. Semi-permanent bodies of water at low tide support greater species richness. They act as stable brackish lake systems, offering continuous refuge and food over 
Table 1. Observations made at managed realignment sites

\begin{tabular}{|c|c|c|c|}
\hline Site & Dates & Observations & Species and numbers \\
\hline $\begin{array}{l}\text { Abbotts Hall } \\
\text { managed } \\
\text { realignment }\end{array}$ & $\begin{array}{l}\text { June } 2003 \\
\& \\
\text { July } 2003\end{array}$ & $\begin{array}{l}\text { Larger grey mullet }(30 \mathrm{~cm}+) \text { were observed entering } \\
\text { the breach on the flood tide feeding at the surface } \\
\text { and leaving just before the tide began to ebb } \\
\text { Nocturnal sampling produced larger bass } \\
(25-35 \mathrm{~cm}) \text { in the fixed nets, which were not observed } \\
\text { during daylight sampling } \\
\text { Unidentified fry at }<10 \mathrm{~mm} \text { were observed } \\
\text { associated with stands of vegetation in the high in- } \\
\text { tertidal areas }\end{array}$ & $\begin{array}{l}\text { Juvenile bass, sand-smelt, smelt, flounder, } \\
\text { common and sand goby, eel, herring, three } \\
\text { spined stickleback and thick and thin lipped } \\
\text { mullet captured } \\
\text { Stickleback and gobies were very abundant } \\
\text { Total catch of } 1697 \text { fish } \\
\text { [Approximately } 20000 \text {-group herring were } \\
\text { also taken in one seine net haul in a perma- } \\
\text { nent saltwater pond which had been an old } \\
\text { freshwater borrow pit] }\end{array}$ \\
\hline $\begin{array}{l}\text { Orplands } \\
\text { managed } \\
\text { realignment }\end{array}$ & August 2003 & $\begin{array}{l}\text { Juvenile sand-smelt in large numbers moved onto } \\
\text { adjacent saltmarsh once tidal height covered veget- } \\
\text { ation enough to eliminate stranding and left just } \\
\text { before the ebbing tide started. School bass at } 25- \\
40 \mathrm{~cm} \text { were observed (and captured on rod and line) } \\
\text { moving into the area just beyond the breaches on the } \\
\text { ebbing tide }\end{array}$ & $\begin{array}{l}\text { Eel, bass, common goby and sand- smelt } \\
\text { captured } \\
\text { Total catch of } 862 \text { fish }\end{array}$ \\
\hline \multirow[t]{2}{*}{$\begin{array}{l}\text { Millenium } \\
\text { Terraces }\end{array}$} & August 1998 & - & $\begin{array}{l}\text { Flounder, dace and goby captured } \\
\text { Total catch of } 49 \text { fish }\end{array}$ \\
\hline & August 2003 & $\begin{array}{l}\text { Smelt were found to be feeding far into vegetation } \\
\text { within reed beds } \\
\text { [New techniques from those deployed in } 1998 \text { were } \\
\text { developed for the } 2003 \text { sampling] }\end{array}$ & $\begin{array}{l}\text { Bass, flounder common goby, roach and } \\
\text { smelt captured } \\
\text { Total catch of } 205 \text { fish }\end{array}$ \\
\hline $\begin{array}{l}\text { Egypt Bay } \\
\text { relic } \\
\text { saltmarsh }\end{array}$ & $\begin{array}{l}\text { November } \\
2003\end{array}$ & - & $\begin{array}{l}\text { Common goby, thick lipped mullet, bass, } \\
\text { smelt, flounder, sand goby and eel captured } \\
\text { Total catch of } 104 \text { fish }\end{array}$ \\
\hline $\begin{array}{l}\text { Stanford } \\
\text { Marshes } \\
\text { relic } \\
\text { saltmarsh }\end{array}$ & $\begin{array}{l}\text { November } \\
2003\end{array}$ & - & $\begin{array}{l}\text { Common goby, three spined stickleback, } \\
\text { flounder, thick lipped mullet and bass } \\
\text { captured } \\
\text { Total catch of } 49 \text { fish }\end{array}$ \\
\hline
\end{tabular}

each tidal cycle. The increase in residence time and improved foraging success makes these sites energetically advantageous. Species such as the thick-lipped grey mullet, Chelon labrosus (L.), and sand-smelt, Atherina presbyter (Cuvier), were abundant in the eastern marsh at Abbotts Hall, and a catch of approximately 2000, 0-group herring, Clupea harengus (L.), was recorded in the western marsh (Fig. 6), demonstrating both current microhabitat utilisation by fish and potential habitat value.

Flounder, Platichthys flesus (L.), was found in abundance at Abbotts Hall during the summer sampling period. The euryhaline post-larvae migrate up the Thames estuary into freshwater reaches in May and June (Colclough et al. 2002). The threespined stickleback, Gasterosteus aculeatus (L.), is also a euryhaline species, explaining its abundance and potentially pioneering role within the restored saltmarsh. Although the common goby, Pomatoschistus microps (Kroyer), is more tolerant of freshwater conditions than the sand goby, Pomatoschistus

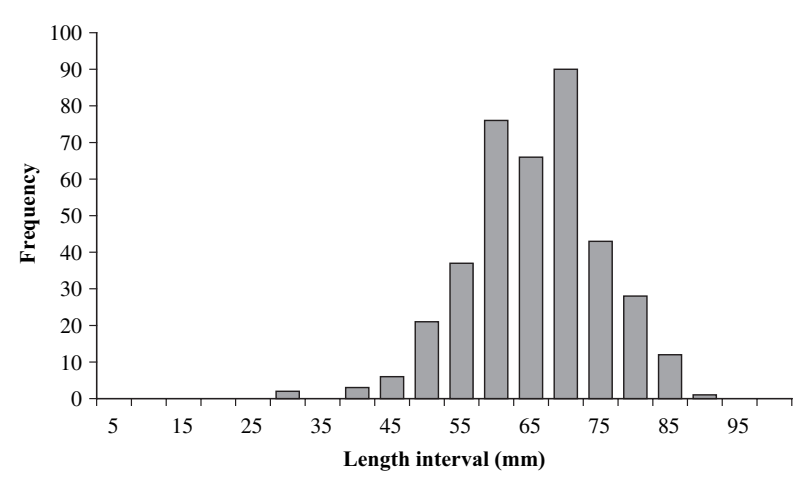

Figure 6. Length frequency distribution for herring $(n=385)$ from former decoy pond at Abbotts Hall.

minutus (Pallas), both species were ubiquitous at Abbotts Hall, with evidence of spawning and recruitment on the site.

At Orplands, the static net deployed on the flood tide was efficient during the day, catching over half the total fish caught during the sampling regime. The 
observation of large piscivorous bass moving to the edges of the breach during the ebb tide may be to predate upon fry seeking refuge after being driven off the marsh at low tide (Hettler 1989). Bass are known to utilise shallow creek-edge habitats at high tide, possibly to avoid larger predators or strong currents and to feed (Fore \& Baxter 1972; Laffaille et al. 2001). Observations of sand-smelt entering the flooded field around high tide, suggest that these fry hesitate in the mid-water column until both the water depth and velocity are sufficient to allow suitable protection for further penetration into the saltmarsh vegetation and cryptic habitat. The fish may utilise increased turbidity, which reduces visibility and therefore offers further protection from predators. This observation was made in the vegetated stands linked by an old artificial trench leading from the saltmarsh vegetation to the breach.

On the Millenium Terraces, the design of the terraces with $90^{\circ}$ angle frontages appears to prevent demersal species, such as flounder, from using the terraces. Larger gobies $(20-44 \mathrm{~mm})$, which are also demersal, were present but do not appear to be using the terraces, whereas smaller gobies $(10-18 \mathrm{~mm})$, which tend to swim mid-column, move onto the terraces during inundation. Smelt, Osmerus eperlanus (L.), was found at the back of the terraces deep in the vegetation and also in front of the terraces in close association with the vegetation. The Millenium Terraces represent the only intertidal vegetated habitat in this reach of the tidal Thames, and as such provide a vital new area for both invertebrates and fish.

The relic saltmarshes sampled on the Thames provide some diverse perspectives. Spartina is well established on Stanford Marshes, elevating the marsh and increasing sediment accretion, in turn raising the marsh further. The net result is that tidal inundation is less frequent, slowing the water velocity, even through the most exposed creeks. As a result, the static net deployed in a well developed creek on a spring tide, was completely dry. The vegetation itself is denser than the pioneer succulents, such as glasswort, Salicornia europaea (L.), found on younger marshes and may be acting as a barrier to fish access. Semi-permanent water bodies, such as the trench, were found to be important for fish. There was a higher fry diversity in this habitat than creeks draining off the saltmarsh. At Egypt Bay, two moist salt pans yielded superabundant populations of Palaemon species. These semi-permanent microhabitats, again surrounded by dense Spartina, may provide an important isolated food source for fry if they can access it on high spring tides.

\section{Discussion}

The results of this study support the work reported by others on the utilisation of saltmarsh habitats by fish and their behaviour during such periods. The observations made at Abbotts Hall and Orplands concur with Laffaille et al. (2000) who suggested that, although European fishes are not considered marsh resident because they can only enter the marsh on spring tides, fish colonise the saltmarsh every time the tide reaches the creeks. The range of euryhaline and eurythermal fish species reported in this study is similar to that reported by Laffaille et al. (2000), including mullets, C. labrosus and Chelon ramada (L.), flounder, gobies and bass.

The majority of fish taken in the present study were juveniles. Shenker \& Dean (1979) highlighted a high degree of utilisation of intertidal creek habitat by larval and juvenile fishes, and stated that differences in diurnal and nocturnal activity, coupled with variation in catch sizes, serve to reduce space and energy competition.

Bass was one of the more common species captured at Abbotts Hall and Orplands. Catches were dominated by the $0+$ year class, with a small number of larger individuals. In their first summer, bass favour shallow creeks, channels, marsh pools and tributary streams, particularly Spartina marshes (Kelley 1988). The nocturnal presence of large bass at Abbotts Hall confirms observations by Copp \& Jurajda (1993), who found a significantly greater number of potentially piscivorous fishes at night. Saltmarsh habitats are too shallow for larger fish to risk entering during daylight hours for feeding, for risk of stranding or predation by birds. A strong positive correlation was also found between water depth and number of piscivorous fishes in a temperate southern African estuary (Paterson \& Whitfield 2000).

Peterson \& Turner (1994) noted that optimal fish utilisation of saltmarshes was observed in systems with gradual sloping edge profiles, well dissected by small drainage features which flood and drain on a regular tidal schedule. The observations made at Abbotts Hall, Orplands and the Millenium Terraces tend to support this view.

\section{Sampling}

Saltmarsh habitats contain a whole series of spatial and temporal microhabitats, highlighting the necessity both to sample at a range of scales (Zedler 2000) and to preview each site over a full tidal cycle to make initial judgements about the suitability of different sampling 
methods. Continuous redistribution and clustering of fry in these high intertidal habitats means that the value of combining static nets with a variety of mobile sampling gear in a highly adaptive manner cannot be stressed enough.

The rate at which fish leave the saltmarsh over the short period of the ebbing tide is related to the relative volume of water leaving the marsh channels and species behaviour. As timing may be indicative of wider fry behavioural trends it should be recorded as part of the assessment.

Nocturnal sampling should be included in monitoring regimes, as daytime sampling biases may limit understanding of fish utilisation of saltmarshes. Vegetated areas, in particular, offer nocturnal refuge for small fish (Copp \& Jurajda 1993; Rountree \& Able 1997).

Seasonal variation plays a large role in the relative proportions of species utilising saltmarsh, as well as fry feeding ecology (Bozeman \& Dean 1980; Claridge \& Potter 1983; Rountree \& Able 1992; Madon, Williams, West \& Zedler 2001; Colclough et al. 2002), therefore seasonal monitoring is required. Laffaille et al. (2000) suggested that marine species that are only infrequently found in intertidal areas (marine stragglers), together with marine estuarine-dependant species, enter the intertidal areas of Mont-Saint Michel Bay (France) in large numbers, colonising marshes in the bay through the recruitment period of spring and autumn before returning to deeper waters. Estuarine fishes are present all year round with maximum abundance in the autumn.

Fish assessments, such as those reported here, will improve the economic justification of managed realignment schemes, thereby reducing the dependency on the compensatory habitat argument and the demands of the European Habitats Directive (Ledoux 2003). However, in highly dynamic heterogeneous saltmarsh habitats it is important to recognise that quantitative nursery assessments will be inaccurate and meaningless if the methods available are used without understanding the system.

Longer-term temporal saltmarsh comparisons will enable the establishment of the rate and stage at which restored UK saltmarsh habitats become valuable to fish. The development of vegetation density, diversity, elevation and canopy height all contribute to variations in fish utilisation (Keer \& Zedler 2002). A study of saltmarsh biological productivity and diversity, soil development, and microbial processes in North Carolina, compared eight, 1-8-year-old created marshes with eight natural marshes (Craft, Megonial, Broome, Stevenson, Freese, Cornell, Zheng \& Sacco 2003).
After 5-15 years, most created marsh ecological attributes were equivalent to natural marshes, whilst young created marshes (1-3 years old) were greater nitrogen sequesters than reference marshes. It is estimated that only $0.5-1 \%$ surface soil organic carbon content would be required to sustain vital heterotrophic activity (Craft, Reader, Sacco \& Broome 1999; Craft et al. 2003; Craft \& Sacco 2003). There is a requirement to broaden comprehension of long-term ecological differences between relic and restored saltmarsh in the UK, especially with the possibility that pioneer vegetation forms a more suitable refuge habitat for fry and their invertebrate food supplies than more dense, ligneous vegetation, such as Spartina.

\section{Site design}

This study has pointed to the potential benefits of channel edge and drainage in juvenile fry production. These factors are regulated by the larger spatial landscape factors that determine stream order (Simenstad, Hood, Thom, Levy \& Bottom 1998). Williams \& Zedler (1999) established such links with fish abundance by locally measuring channel habitat characteristics, including hydrology, stream order, width, maximum depth, bank slope, water quality and sediment composition. Bifurcation points between first and second order channels act as ecological hot spots, especially for fish (Simenstad et al. 1998). This concurs with findings in the present study at Orplands, where large bass, having entered from the breach, were observed waiting in the creek confluences, and where sand-smelt were observed in the deeper water of the trench waiting to enter the smallest saltmarsh creeks. At Orplands, managed realignment, dredging, digging channels and planting vegetation were used to accelerate marsh development using hydrodynamic modelling to imitate the natural environment. Depending on marsh capacity, the residence time of fry may be increased with an improved creek system. A lower diversity, but higher abundance of mainly gobiid fry, was found in first-order intertidal creeks relative to larger creeks in saltmarshes in southern California (Desmond, Zedler \& Williams 2000), and it is recommended that consideration of the construction of such structure should be incorporated into restoration designs at similar sites (Desmond et al. 2000).

Proximity to fish spawning sites is an important consideration in site selection as restored saltmarsh habitat is more likely to be successful in this circumstance. This suggestion is based upon the large catches (in excess of 2000 fish) of 0-group herring at Abbotts Hall, which is situated close to a known herring 
spawning site on the Blackwater estuary (Fox, Harrop \& Wimpenny 1999).

Site topography is an important consideration in the redevelopment process because in areas of steep topography, horizontal tidal inundation may be limited, reducing the requirement to build a new sea wall, therefore lessening the economic and ecological costs markedly. The replacement of a flood defence wall requires direct encroachment by, on average, $2 \mathrm{~m}$ for construction. Although this process may have minimal hydraulic impact when the toe of the wall is in the high intertidal, recruitment is affected as fish nursery and feeding grounds are damaged (HR Wallingford 1996). A natural slope will also enable the establishment of a transitional plant community providing fish refugia.

\section{Vegetation}

The importance of saltmarsh vegetation for foraging pelagic fish was highlighted. Marsh plants provide vital refugia, increased surface area for food sources, and, potentially, fry spawning sites during high tide (McIvor \& Odum 1988). Provided the vegetation is not too dense, fry exhibit a preference for marsh access from semi-permanent tidal creeks and channels with shallow sloping profiles. Indeed, access is suggested to be the limiting factor in feeding, and therefore growth rates, of California killifish, Fundulus parvipinnis Girard, fry on Californian saltmarshes (Madon et al. 2001). Vegetation is especially important for the youngest fry, which were found at Abbotts Hall in the highest intertidal reaches at the freshwater-brackish interface. In addition, submerged aquatic vegetation adjacent to saltmarsh may also enhance fish habitat value, enabling fish to consume larger prey thereby increasing growth rates and fecundity, and reducing mortality (Rosas \& Odum 1987; Irlandi \& Crawford 1997). The shape and form of the realignment should be designed in an appropriate manner to reduce requirements for specific saltmarsh planting before the breach, and reduce the need for human intervention, and its consequent impacts, after the breach. Timing can also have marked effects on the rate of vegetation establishment. Pioneer halophyte seedling establishment occurs in spring, and can occur within the first spring after a breach, if the soil has been tidally inundated for long enough to create optimum soil chemistry and texture. Regulated tidal exchange in advance of full breaching, as practised at Abbotts Hall, can only facilitate establishment.

Successful ecological restoration of saltmarsh fry habitat, relies upon understanding that managed realignments are in a state of dynamic equilibrium, both spatially and temporally. The technology to predict alternative ecological states on the landscape scale, for example through hydrological and sediment modelling, is steadily improving, especially because of escalating political and economic interest in this subject. Fry nursery functions of such habitats are only just beginning to be described. The current study has become an integral part of the European Interreg IIIb project COMCOAST (http://www.comcoast. org/), spanning five European countries. The project deals with the identification and understanding of all the social, economic and technical opportunities and constraints in innovative coastal risk management needed to deliver a more sustainable environment. As work progresses, recommendations on fish sampling rationales and site design to maximise fish benefits will be available to practitioners.

\section{Acknowledgments}

Thanks are due to the Environment Agency, Thames Estuary Partnership, Essex Wildlife Trust and English Nature for financial and material support. In particular thanks are due to Rachael Hill, Sarah Lavery, Tim Chapple, Dave Smart, John Ducker, Chris Conroy, Matthew Robson, Sarah White, Chris Dutton, Tom Cousins, Martin Davy, John Hall, Mark Dixon, Dick Weight, Jo Carrington and Carol Reid.

\section{References}

Attrill M.J., Bilton D.T., Rowden A.A., Rundle S.D. \& Thomas R.M. (1999) The impact of encroachment and bankside development on the habitat complexity and supralittoral invertebrate communities of the Thames Estuary foreshore. Aquatic Conservation - Marine and Freshwater Ecosystems 9, 237-247.

Bell F.W. (1997) The economic valuation of saltwater marsh supporting marine recreational fishing in the southeastern United States. Ecological Economics 21, 243-254.

Boesch D. \& Turner R. (1984) Dependence of fishery species on saltmarshes: the role of food and refuge. Estuaries 7, 460-468.

Bozeman E.L. \& Dean J. (1980) The abundance of estuarine larval and juvenile fish in a South Carolina intertidal creek. Estuaries 3, 89-97.

Claridge P.N. \& Potter I.C. (1983) Movements, abundance, age composition and growth of bass, Dicentrarchus labrax, in the Severn Estuary and inner Bristol Channel. Journal of the Marine Biological Association UK 63, 871-879.

Colclough S.R., Gray G., Bark A. \& Knights B. (2002) Fish and fisheries of the tidal Thames: management of the 
modern resource, research aims and future pressures. Journal of Fish Biology 61(Suppl. A), 64-73.

Colclough S.R, Coates S., Dutton C., Cousins T. \& Astley T. (2003) The potential for fisheries enhancement associated with managed realignment. In: L. Ledoux (ed.) Wetland Valuation: State of the Art and Opportunities for Further Development. Proceedings of a workshop organised for the Environment Agency by Environmental Futures Ltd and CSERGE. Bristol: Environment Agency, pp. 50-65.

Copp G.H. \& Jurajda J. (1993) Do small riverine fish move inshore at night? Journal of Fish Biology 43(Suppl. A), 229-241.

Craft C. \& Sacco J. (2003) Long-term succession of benthic infauna communities on constructed Spartina alterniflora marshes. Marine Ecology Progress Series 257, 45-58.

Craft C., Reader J., Sacco J.N. \& Broome S.W. (1999) Twenty-five years of ecosystem development of constructed Spartina alterniflora (Loisel) marshes. Ecological Applications 9, 1405-1419.

Craft C., Megonial P., Broome S., Stevenson J., Freese R., Cornell J., Zheng L. \& Sacco J. (2003) The pace of ecosystem development of constructed Spartina alterniflora marshes. Ecological Applications 13, 1417-1432.

Crooks S. \& Turner R.K. (1999) Integrated Coastal Management: sustaining estuarine natural resources. Advances in Ecological Research 29, 241-289.

Desmond J.S., Zedler J.B. \& Williams G.D. (2000) Fish use of tidal creek habitats in two southern California saltmarshes. Ecological Engineering 14, 233-252.

Dixon A.M., Leggett D.J. \& Weight R.C. (1998) Habitat creation opportunities for landward coastal re-alignment: Essex case studies. Journal of the Chartered Institute of Water and Environmental Management 12, 107-111.

Elliott M. \& Taylor C.J.L. (1989) The Structure and Functioning of an Estuarine/marine Fish Community in the Forth estuary, Scotland. Proceedings of the 21st European Marine Biology Symposium, Gdansk, September 1986. Gadansk: Polish Academy of Sciences, Institute of Oceanology, pp. 227-240.

Fore P.L. \& Baxter K.N. (1972) Diel fluctuations in the catch of larval Gulf Menhaden, Brevoortia patronus at Galveston Entrance Texas. Transactions of the American Fisheries Society 101, 729-732.

Fox C.J., Harrop R. \& Wimpenny A. (1999) Feeding ecology of herring (Clupea harengus) larvae in the turbid Blackwater Estuary. Marine Biology 134, 353-365.

Hemingway K. \& Elliott M. (2002) Field Methods. In: M. Elliott \& K.L. Hemingway (eds) Fishes in Estuaries. Oxford: Blackwell Science, pp. 410-509.

Hettler W.F. (1989) Nekton use of regularly-flooded saltmarsh cordgrass habitat in North Carolina, USA. Marine Ecology Progress Series 56, 111-118.
HR Wallingford (1996) Tidal Thames Encroachment Study. Oxford: HR Wallingford, $82 \mathrm{pp}$.

Irlandi E.A. \& Crawford M.K. (1997) Habitat linkages: the effect of intertidal saltmarshes and adjacent subtidal habitats on abundance, movement, and growth of an estuarine fish. Oecologia 110, 222-230.

Keer G.H. \& Zedler J.B. (2002) Saltmarsh canopy architecture differs with the number of and composition of species. Ecological Applications 12, 456-473.

Kelley D.F. (1988) The importance of estuaries for sea-bass Dicentrarchus labrax (L.). Journal of Fish Biology 33(Suppl. A), 25-33.

Klein R.J.T., Smit M.J., Goosen H. \& Hulsbergen C.H. (1998) Resilience and vulnerability: Coastal dynamics or Dutch dykes? Geographical Journal 164, 259-268.

Laffaille P., Feunteun E. \& Lefeuvre J.-C. (2000) Composition of fish communities in a European macrotidal saltmarsh (the Mont Saint-Michel Bay, France). Estuarine, Coastal and Shelf Science 51, 429-438.

Laffaille P., Lefeuvre J.-C., Schricke M.-T. \& Feunteun E. (2001) Feeding ecology of 0-group sea bass, Dicentrarchus labrax, in saltmarshes of Mont Saint Michel Bay (France). Estuaries 24, 116-125.

Leafe R., Pethick J. \& Townend I. (1998) Realising the benefits of shoreline management. Geographical Journal 164, 282-290.

Ledoux L.(ed.) (2003) Wetland Valuation: State of the Art and Opportunities for Further Development. Proceedings of a Workshop Organised for the Environment Agency by Environmental Futures Ltd. and CSERGE. Bristol: Environment Agency, pp. 5-17.

Lyndon A.R., Bryson J.G., Holding N. \& Moore C.G. (2002) Feeding reationships of fish using intertidal habitats in the Forth estuary. Journal of Fish Biology 61(Suppl. A), 74-80.

Madon S.P., Williams G.D., West J.M. \& Zedler J.B. (2001) The importance of marsh access to growth of the California killifish, Fundulus parvipinnis, evaluated through bioenergetics modelling. Ecological Modelling 136, 149-165.

Mathieson S., Cattrijsse A., Costa M.J., Drake P., Elliott M., Gardner J. \& Marchand J. (2000) Fish assemblages of European tidal marshes: a comparison based on species, families and functional guilds. Marine Ecology Progress Series 204, 225-242.

McIvor C.C. \& Odum W.E. (1988) Food, predation risk and microhabitat selection in a marsh fish assemblage. Ecology 69, 1341-1351.

McLusky D.S., Bryant D.M. \& Elliott M. (1992) The impact of land-claim on macrobenthos, fish and shorebirds on the Forth estuary, eastern Scotland. Aquatic Conservation: Marine and Freshwater Ecosystems 2, 211-222.

Paterson A.W. \& Whitfield A.K. (2000) Do shallow-water habitats function as refugia for juvenile fishes? Estuarine Coastal and Shelf Science 51, 359-364. 
Peterson G. W. \& Turner R. E. (1994) The value of saltmarsh edge vs. interior as a habitat for fish and decapod crustaceans in a Louisiana tidal marsh. Estuaries 17(1B), 235.

Rosas L.P. \& Odum W.E. (1987) Use of tidal freshwater marshes by fishes and macrofaunal crustaceans along a marsh stream-order gradient. Estuaries 10, 36-43.

Rountree R.A. \& Able K.W. (1992) Foraging habits, growth and temporal patterns of salt-marsh creek habitat use by young of year summer Plounder in New Jersey. Transactions of the American Fisheries Society 121, 765-776.

Rountree R.A. \& Able K.W. (1997) Nocturnal fish use of a New Jersey marsh creek and adjacent bay shoal habitats. Estuarine, Coastal and Shelf Science 44, 703-711.

Rupp S. \& Nicholls R.J. (2002) Managed realignment of coastal flood defences: a comparison between England and Germany. In: B. Van Kappel (ed.) Proceedings of "Dealing with Flood Risk" Interdisciplinary Seminar of the Regional Implications of Modern Flood Management. Delft: Delft Hydraulics, pp. 1-9.
Shenker J.M. \& Dean J.M. (1979) Larval and juvenile fishes in saltmarshes. Estuaries 2, 154-163.

Simenstad C.A., Hood W.G., Thom R.M., Levy D.A. \& Bottom D.L. (1998) Landscape structure and scale constraints on restoring estuarine wetlands for Pacific Coast juvenile fishes. Meeting on Concepts and Controversies in Tidal Marsh Ecology APR, 597-630.

Southward A.J. (1970) Improved methods of sampling postlarval young fish and macroplankton. Journal of the Marine Biological Association UK 50, 689-712.

West J.M. \& Zedler J.B. (2000) Marsh-creek connectivity: fish use of a tidal saltmarsh in Southern California. Estuaries 23, 699-710.

Williams G.D. \& Zedler J.B. (1999) Fish assemblage composition in constructed and natural tidal marshes of San Diego Bay: relative influence of channel morphology and restoration history. Estuaries 22, 702-716.

Zedler J.B. (2000) Progress in wetland restoration ecology. TREE 15, 402-407. 